\title{
Design of Dual-Polarized Compact Quad Band Metamaterial Antenna
}

\author{
Niraj Kumar*, Ravi Prakash Dwivedi†, Priyanka Usha, Richa Dubey, Ankit Arora \\ School of Electronics Engineering, Vellore Institute of Technology, Chennai, India
}

(Received 10 January 2021; revised manuscript received 15 June 2021; published online 25 June 2021)

\begin{abstract}
A compact novel quad-band compact antenna with dual polarization characteristics is designed and implemented using metamaterial. The proposed antenna is designed with matched phase shifted microstrip line and fed rotated microstrip patch antenna embedded with split ring resonator (SRR). The antenna operates at four separate impedance bandwidth of $500 \mathrm{MHz}(1.13-1.63 \mathrm{GHz}), 640 \mathrm{MHz}(2.05-$ $2.69 \mathrm{GHz}), 470 \mathrm{MHz}(4.86-5.33 \mathrm{GHz})$ and $950 \mathrm{MHz}(7.1-8.05 \mathrm{GHz})$. With the use of $\lambda / 4$ phase-shifted matched feed, the circular polarization is realized and verified with experimental setup. Finally, both the linear and circular polarization is obtained for each band and is observed using Axial Ratio (AR). The metamaterial properties are extracted using periodic boundary conditions. The prototype of design has also been fabricated and tested using VNA and Anechoic Chamber. It was observed that gain and radiation pattern was perfectly matched for simulated and measured prototype, this makes proposed antenna a suitable candidate for wireless application.
\end{abstract}

Keywords: Dual polarization, Metamaterial, Quad band.

DOI: 10.21272/jnep.13(3).03037

PACS numbers: 78.67.Pt, 81.05.Xj, 84.40.Ba

\section{INTRODUCTION}

The demand for the compact antennas with multiband resonance has increased in this rapid growing era of wireless systems $[1,2]$. The need for cost-effective, viable and high-speed connectivity solution encouraged the use of WLAN (Wireless Local Area Network) band [3] and with the progressive development in Internet of Things (IoT) field, the requirement of peer-to-peer connection is the need for the hour, hence the WPAN (Wireless Personal Area Network) band is the coming into picture [4]. In addition to these, for the reducing multipath and antenna orientation constraints, the Circular Polarization (CP) is a good choice. Also, the ability of CP antenna to provide better mobility and operate better in dreadful weather takes it one step ahead of Linear Polarized (LP) antenna [5]. Hence, the multi-band dualpolarized antenna is requisite in a single antenna [6].

To fulfill the need for multi-band and dually polarized operation, such antenna has to be of easy design and fabrication to get cost-effectiveness, compactness in size and quick and easy integration with transceiver's front-end circuitry [7]. The good option in this requirement run is the microstrip patch antennas having the stable trade-off in all parameters say it is bandwidth, gain, cost-effectiveness, or return loss, in comparing to use monopoles, dipoles, arrays, stacking technique, stepped slot resonators, etc. [8-10] This somehow lack such stable trade-offs. Also, there are some easy techniques for obtaining the $\mathrm{CP}$ in Microstrip patch antennas. With the numerous operational techniques in microstrip patch, multi-band resonance is possible.

In this paper, relatively compact quad-band $\lambda / 4$ phase-shifted matched microstrip-fed patch antenna is proposed for Wireless application band (for wireless links, security cameras, video transmission, etc.), WLAN and WPAN band applications. With Split Ring
Resonator (SRR) embedded with patch design and rotate structure and $\lambda / 4$ phase-shifted matched feed antenna [10] provides four bands with impedance bandwidth of $500 \mathrm{MHz}, 640 \mathrm{MHz}, 470 \mathrm{MHz}$ and $950 \mathrm{MHz}$ with corresponding frequency bands of $1.13-1.63 \mathrm{GHz}$, 2.05-2.69 GHz, $4.86-5.33 \mathrm{GHz}$ and $7.1-8.05 \mathrm{GHz}$, respectively. Also, the dual polarization is realized using the Axial Ratio (AR) across each band. In addition, antenna shows stable antenna gains across the operating bands. Moreover, the simplicity of design takes it a step ahead. The detailed discussion on geometry and experimental results are done in following sections.

\section{METAMATERIAL PROPERTIES EXTRACTION ANALYSIS}

\subsection{Nicolson-Ross-Weir (NRW) Process}

Metamaterial properties extraction using $S$ parameter, SRR cell is placed between two waveguide ports at the top and bottom on the $Z$-axis as shown in Fig. 1. Also, the $X$ - plane is constructed as PEB (Perfect Electric Boundary) and $Y$-plane is constructed as PMB (Perfect Magnetic Boundary); thus, the internal environment of the waveguide is created.

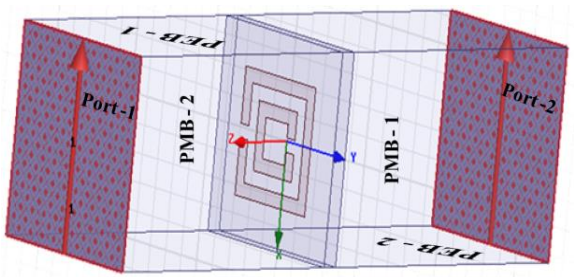

Fig. 1 - SRR unit cell and waveguide design configuration

For satisfying the theory of change in nature of the material due to the presence of metamaterial is ob-

\footnotetext{
* nirajkumar@vit.ac.in

† raviprakash.dwivedi@vit.ac.in

The results were presented at the International Conference on Innovative Research in Renewable Energy Technologies (IRRET-2021)
} 
served in Fig. 2, where the permittivity and permeability of the material are calculated, visualized and the unnatural negative behavior is observed in the operating range with the variation in ' $s$ ' and ' $w$ i'parameter of the design.

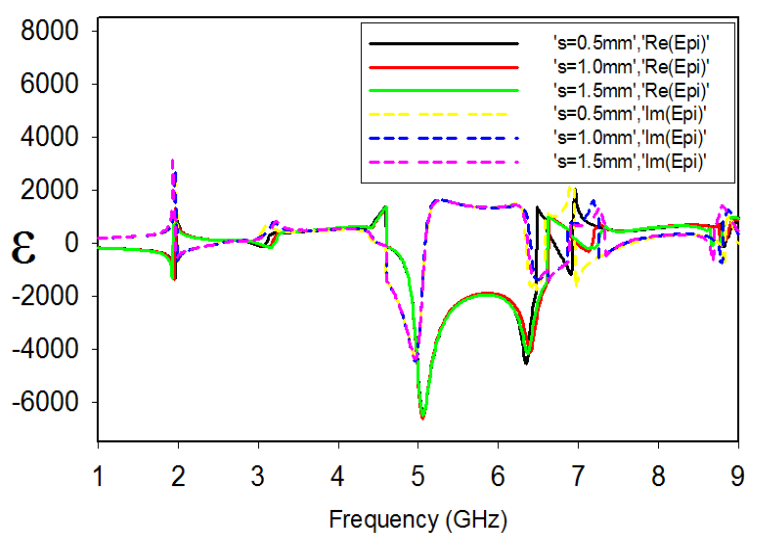

Fig. 2 - Variation of permittivity versus frequency

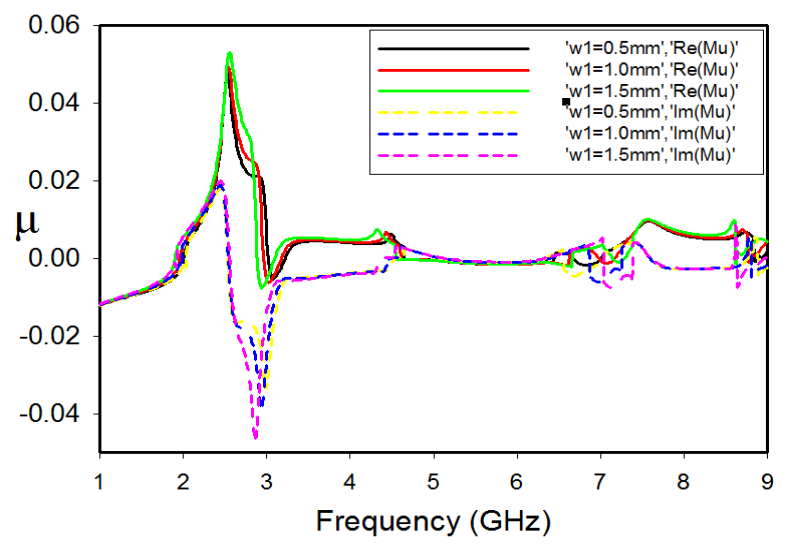

Fig. 3 - Variation of permeability versus frequency

\subsection{Antenna Design and Analysis}

The detailed configuration and fabricated prototype of the proposed antenna are shown in Fig. 4 and Fig. 5, respectively. The antenna is constructed on the FR4epoxy substrate with a relative dielectric constant of 4.4 , loss tangent of 0.02 and thickness of $1.6 \mathrm{~mm}$. It consists of a partial ground and a rotated structure having a patch and SRR structure embedded in it, excited using a single feed. This feed later split into two, each providing a $90^{\circ}$ phase difference with respect to

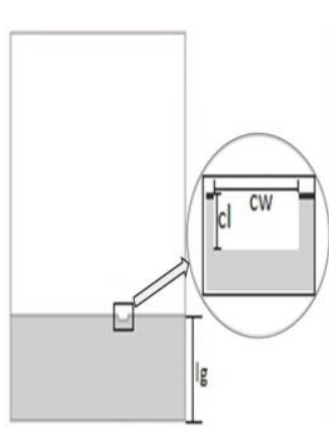

a

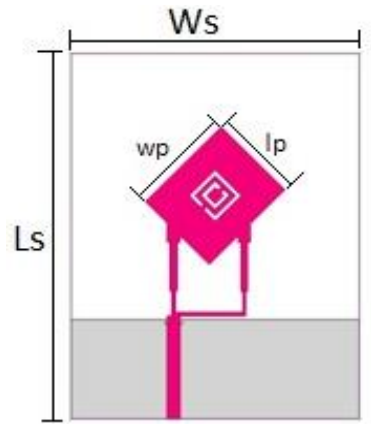

$\mathrm{b}$

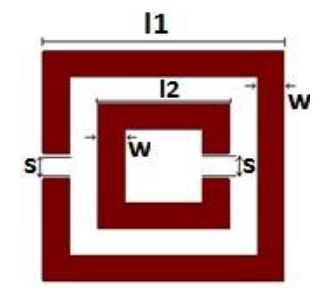

Fig. 4 - Configuration of the proposed antenna, where: a) top view, b) back view with a cut in the ground, c) SRR structure

each other, obtained using $\lambda / 4$ phase-shifted matched feed. This type of feed is used for obtaining the circular polarization. The design parameters are stated in Table 1 and Table 2 .

Table 1 - Proposed antenna designs' values

\begin{tabular}{|l|l|l|l|}
\hline Parameter & Value $(\mathrm{mm})$ & \multicolumn{1}{|c|}{ Parameter } & Value $(\mathrm{mm})$ \\
\hline$L_{s}$ & 90 & $W_{s}$ & 70 \\
\hline$l_{p}$ & 21.9879 & $w_{p}$ & 26.082 \\
\hline$l_{g}$ & 24.4685 & $c l \times c_{w}$ & $2 \times 4.06$ \\
\hline$l_{1}$ & 8.980775 & $l_{2}$ & 4.888 \\
\hline$s$ & 1 & $w$ & 1 \\
\hline$h$ & 1.6 & Angle (in ACW) & $45 \mathrm{deg}$ \\
\hline
\end{tabular}
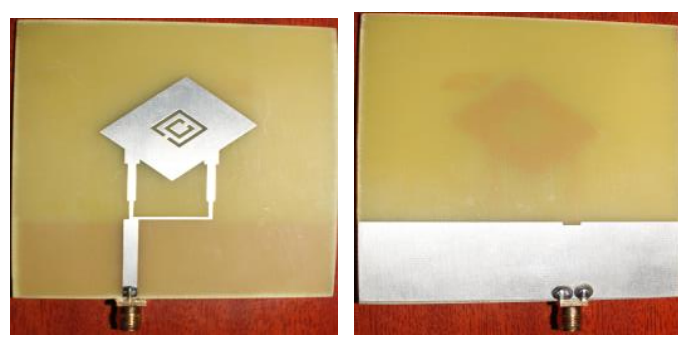

Fig. 5 - Fabricated prototype of the proposed antenna

The comparative variation in $S_{11}$ for each stage as shown in Fig. 6, is verifying each stage of evolution the path to next stage, leading to our final proposed design.

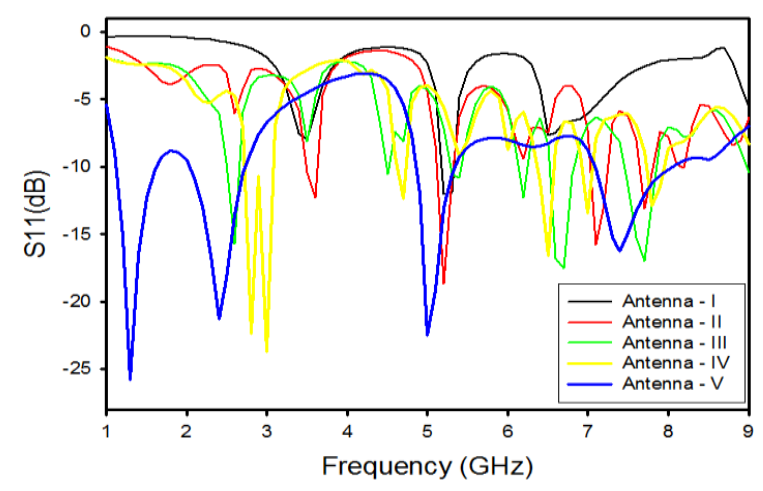

Fig. 6 - $S_{11}$ versus frequency for all evolution stages

\subsection{Results and Discussion}

Fig. 7 illustrates the measured and simulated reflection coefficient $\left(S_{11}\right)$ versus frequency and, $-10 \mathrm{~dB}$ impedance bandwidth is calculated for quad-band. Also, the measured and simulated gain versus frequency is shown in Fig. 8, while Fig. 9 shows the measured 


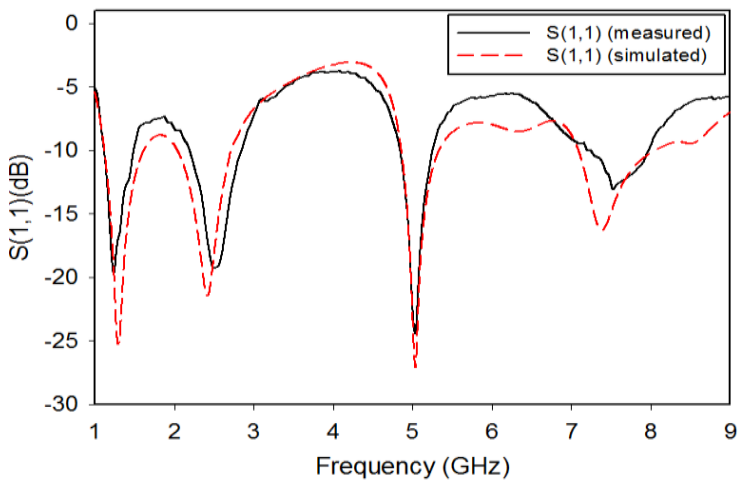

Fig. 7 - $S_{11}$ versus frequency (comparative analysis)

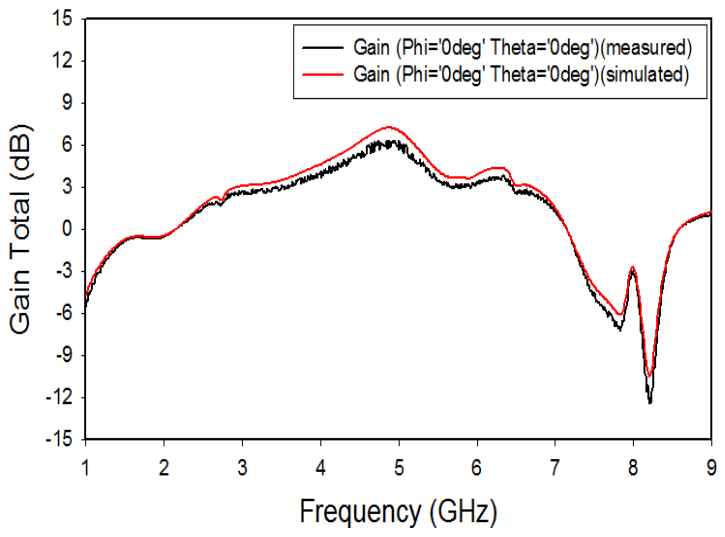

Fig. 8 - Gain versus frequency (comparative analysis)

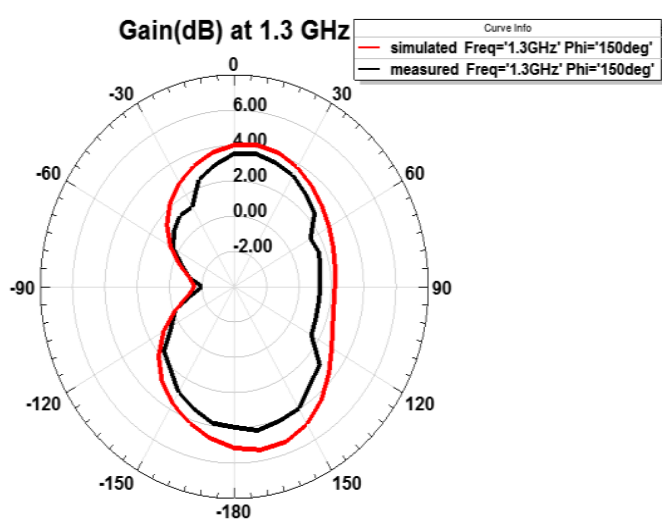

a

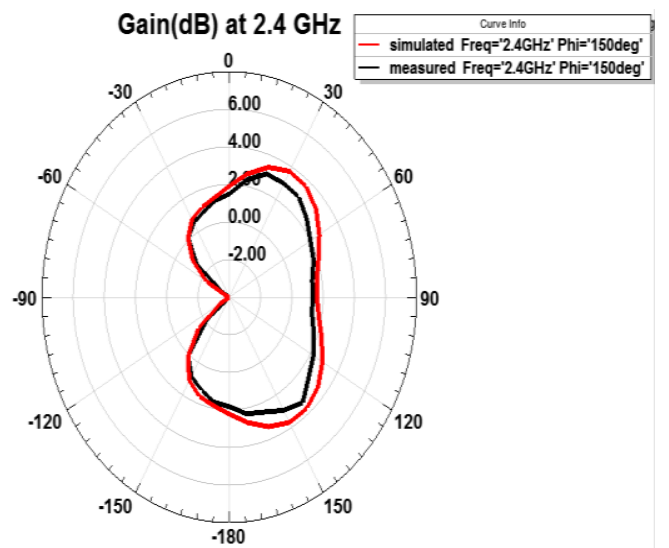

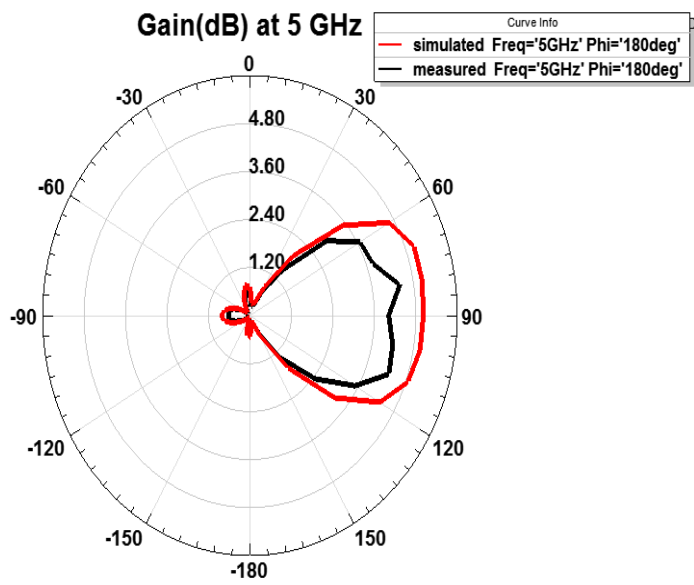

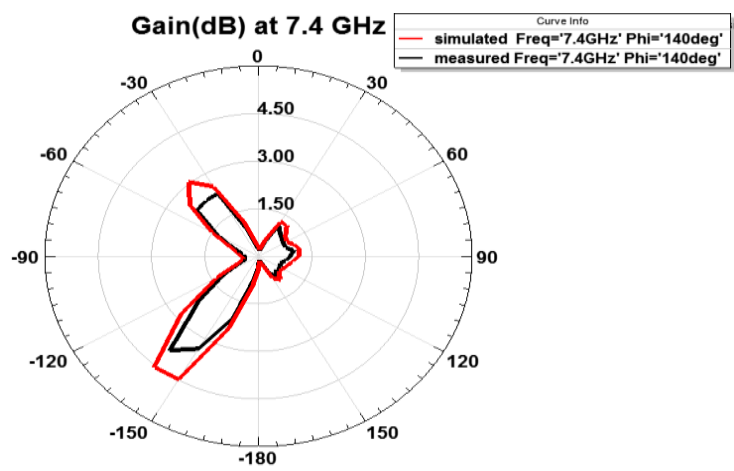

d

Fig. 9 - Radiation pattern for maximum gain at operating frequency: a) gain plot for $1.3 \mathrm{GHz}$, b) gain plot for $2.4 \mathrm{GHz}$, c) gain plot for $5 \mathrm{GHz}$, d) gain plot for $7.4 \mathrm{GHz}$

and simulated radiation pattern (gain versus theta) for each operating frequency. After observing all, it is observed that the measured and simulated results are at an adequate agreement with an acceptable discrepancy in the frequency along with the stable bandwidth and accepted gain of the antenna in quad bands.

Proposed antenna is significantly better in terms of the technique, the substrate used, fabrication simplicity, cost of the antenna, number of bands achieved, size of antenna and type of polarization generated. Hence the proposed design is better than the existing designs while considering the overall dimension.

\section{CONCLUSIONS}

Quad band antenna is implemented with dual polarization. The incorporation of SRR is successfully improved the multi-band resonance. In the process of incorporation of SRR, the materials property is changed. Due to multi-band resonance, the peak gain of each band is found at a different orientation with respect to transmitting antenna. The dual polarization of the antenna helps in improvising the transmission of the signal without interference and it has been analyzed using axial ratio. 


\section{REFERENCES}

1. Ting Wu, Hao Bai, Xi-Zheng Ke, Prog. Electromagnet. Res. Lett. 68, 135 (2017).

2. T.N. Thi, S. Trinh-Van, G. Kwon, K.C. Hwang, Prog. Electromagnet. Res. 143, 207 (2013).

3. X. Li, Y.F. Wang, X.W. Shi, W. Hu, L. Chen, Microw. Opt. Technol. Lett. 54 No 2, 286 (2012).

4. Guanbo Zheng, Cunqing Hua, Rong Zheng, Qixin Wang, IEEE Trans. Mobile Comput. 15 No 3, 762 (2016).

5. S.A. Rezaeieh, Electron. Lett. 47 No 22, 1212 (2011).

6. Kushmanda Saurav, Debdeep Sarkar, Kumar Vaibhav Srivastava, IEEE Anten. Wire. Propag. Lett. 13, 1357 (2014).
7. Saeid Jamilan, Marco A. Antoniades, Javad Nourinia, Mohammad Naghi Azarmanesh, IEEE Antenna. Wire. Propag. Lett. 14, (2015).

8. Hyuk-Jun Seo, Ahmed A. Kishk, Prog. Electromagnet. Res. 155, 53 (2016).

9. S. Shaik, R.P. Dwivedi, 2017 International Conference on Nextgen Electronic Technologies: Silicon to Software (ICNETS2), 322 (Chennai: 2017).

10. R.K. Saraswat, M. Kumar, Wireless Pers Commun. 114, 3595 (2020).

\title{
Конструкція компактної чотиридіапазонної антени з подвійною поляризаціею, виготовленої з метаматеріалів
}

\author{
Niraj Kumar, Ravi Prakash Dwivedi, Priyanka Usha, Richa Dubey, Ankit Arora \\ School of Electronics Engineering, Vellore Institute of Technology, Chennai, India
}

\begin{abstract}
Нову компактну чотиридіапазонну антену з подвійною поляризацією розроблено та реалізовано $з$ використанням метаматеріалів. Запропонована антена сконструйована з узгодженою мікросмуговою лініею з фазовим зсувом і обертовою мікросмуговою патч-антеною, вбудованою в роз'емний кільцевий резонатор (SRR). Антена працюе в чотирьох окремих діапазонах з шириною смуг пропускання 500 МГц (1.13-1.63 ГГц), 640 МГц (2.05-2.69 ГГц), 470 МГц (4.86-5.33 ГГц) і 950 МГц (7.1-8.05 ГГц). За допомогою узгодженого живлення з фазовим зсувом $\lambda / 4$ реалізуеться кругова поляризація, яка перевіряеться за допомогою експериментальної установки. Нарешті, як лінійна, так і кругова поляризації мають місце для кожної смуги і спостерігаються за допомогою коефіцієнту еліптичності (AR). Властивості метаматеріалів вилучаються за допомогою періодичних граничних умов. Прототип конструкції виготовлений та випробуваний з використанням VNA та звуконепроникної камери. Було помічено, що коефіцієнт підсилення та діаграма спрямованості ідеально узгоджуються для змодельованого та виміряного прототипів, що робить запропоновану антену придатним кандидатом для бездротових додатків.
\end{abstract}

Ключові слова: Подвійна поляризація, Метаматеріал, Чотиридіапазонний. 